\title{
Investigating the prevalence of Bark beetles of Pinus halepensis in the North East semi-arid region of Algeria
}

\author{
LYÈS MOUMENI ${ }^{1,2, \bullet}$, AMANDINE GASTEBOIS ${ }^{2}$, LOUIZA GILLMANN ${ }^{2}$, NICOLAS PAPON ${ }^{2}$, \\ FARIDA BENIA ${ }^{1}$, JEAN-PHILIPPE BOUCHARA ${ }^{2}$, MUSTAPHA BOUNECHADA ${ }^{1}$ \\ ${ }^{1}$ Laboratoire d'amélioration et de développement de la production végétale et animale (LADPVA), Ferhat Abbas University Setif 1. Setif, Algeria. \\ "email: lyes.moumeni@etud.univ-angers.fr. \\ ${ }^{2}$ Groupe d'Etude des Interactions Hôte-Pathogène, GEIHP, EA3142, Université d'Angers. SFR 4208 ICAT, France.
}

Manuscript received: 7 October 2020. Revision accepted: 18 June 2021.

\begin{abstract}
Moumeni L, Gastebois A, Gillmann L, Papon N, Benia F, Bouchara J-P, Bounechada M. 2021. Investigating the prevalence of Bark beetles of Pinus halepensis in the North East semi-arid region of Algeria. Biodiversitas 22: 2755-2762. Aleppo pine is the most common tree in the semi-arid forests of Algeria. Despite its high resistance to drought and adaptability to all types of soils, the effects of climate change are affecting it directly and indirectly. Stressed trees indeed are subject to bark beetle attacks. In this study, we sampled the bark beetles directly from the affected pine trees. Six species belonging to the Scolytinae subfamily were identified. Tomicus detruens and Orthotomicus erosus were widely spread and present in the three studied forests, where they were found to colonize living trees while Crypturgus numidicus, Crypturgus mediterraneus, Hylurgus ligniperda and Hylurgus micklitzi colonized only dead trees. Together with future identification of the microfungi associated with these xylophagous insects, these data may help to define prevention measures to fight the decline of Aleppo pine forests observed in some parts of Eastern Algeria.
\end{abstract}

Keywords: Aleppo pine, bark beetles, forest decline, Scolytinae, semi-arid

\section{INTRODUCTION}

The Aleppo pine (Pinus haleppensis) is the most common tree in Algeria and it has a very important place in the balance of Mediterranean ecosystems. Global warming and its consequences like repeated heatwaves and drought have a significant impact on trees and their predators, resulting in an increased mortality and forest decline (Morcillo et al. 2019). However, trees can withstand the stresses and avoid dieback when favorable conditions return, but biotic factors such as pests can aggravate the stress and lead to their death (Anderegg et al. 2015). Common pests are the pine processionary caterpillars and bark beetles (Lieutier et al. 2016; Bao et al. 2020). These last insects develop in lignified stems and feed on vascular tissues, from the shoots to the tree trunk. Most species develop on decaying trees or dead wood but some species can also colonize stressed living trees (Paine et al. 1997). The females dig a gallery under the bark to deposit their eggs into the cambium (Davi et al. 2020).

Global warming and its effects cause stress and weaken the defense of fragile trees, which facilitates the development of species already existing in the territory and potentially the introduction of new species of bark beetles (Suárez-Vidal et al. 2019). The attack occurs at different levels of plant vitality; some species develop on healthy plants, but many select hosts that are physiologically stressed or injured. The strategy of mass attack is used to overwhelm the defenses of the host. For example, with the aggressive Mediterranean species Tomicus destruens, the bored galleries damage the vascular system (xylem or phloem) and the cambium, resulting in various physiological imbalances (Chakali 2007; Lieutier et al. 2017). Other bark beetle species attack recently dead trees and introduce symbiotic fungi (Ambrosia), and the hatched larvae then feed on the mycelium of these fungi. Some of the bark beetles are known for their association with xylophagous fungi, which can aggravate the mechanical damage caused by the insects leading to dieback. Saproxylophagous insects that only develop in deadwood, are not considered as pests (Sauvion et al. 2013).

Bark beetles or Scolytinae belong to Curculionidae. They are represented worldwide by 6,000 species grouped in 29 tribes (Alonso-Zarazaga and Lyal 2009). In Algeria, 17 coniferous bark beetle species are monitored (Lieutier et al. 2016), but the bark beetle fauna of Algeria was not reviewed recently, and most of the existing records are old. Therefore, the geographical distribution of bark beetle species in Algeria remains to be further clarified. There are no studies that focus on bark beetles in the study region despite the recent forest decline phenomenon.

The main objective of our study was to investigate the distribution of bark beetle species responsible for the decline of the Aleppo pine in the Central-Est semi-arid region of Algeria. 


\section{MATERIALS AND METHODS}

\section{Study area}

The study was carried out in a semi-arid region located in the Hodna and the Bibans Mountains, in North-Eastern Algeria, between $35^{\circ} 41^{\prime} 05.2^{\prime \prime}$ and $36^{\circ} 11^{\prime} 34.0^{\prime \prime}$ latitude (N) and 4 and $5^{\circ}$ longitude (E), and at an altitude of 900-1300 m.

The three forests of Boutaleb, Ouled Tebben and Ouenougha were selected for sampling, taking into account the forest dieback, the surface area of the forests and their ecological importance in the region (Figure 1). The study area is part of the semi-arid bioclimatic domain. Twentythree, 25 and 30 sites were investigated in the Boutaleb, Ouled Tebben and Ouenougha forests, respectively (Figure 1).

The Boutaleb forest ( $28427 \mathrm{ha}$ ) is located between the high Setifian plains to the north and the Hodna basin to the south (3544'21.1"N 5'19'47.9"E, 950-1886 m asl.). The annual rainfall is $468 \mathrm{~mm}$ and the mean annual temperature is $13.3^{\circ} \mathrm{C}$. The Boutaleb massif is exclusively made up of sedimentary rocks (marl, limestone, dolomite and clays with a lesser extension). The vegetation is composed of Aleppo pine (Pinus halepensis Mill.), Atlas cedra (Cedrus allantica Manetti), holm oak (Quercus ilex L.), narrowleaved mock privet (Phillyrea angustifolia L. Rouy), turpentine tree (Pistacia terebinthus L.), lentisk (Pistacia lentiscus L.), Phoenicean juniper (Juniperus phoenicea L.), cade juniper (Juniperus oxycedrus L.), rosemary (Salvia jordanii J.B.Walker), globe daisies (Globularia alypum L.) and hairy thyme (Thymus munbyanus subsp. ciliatus Desf).

The Ouled Tebben forest or Righa Dahra (14932 ha) is located in the east of the Boutaleb forest between the high Setifian plains to the north and the Hodna basin to the south. It is in the middle of three provinces Setif, Bordj Bou Arréridj and M'sila (3548'36.3"N 508'58.5"E, 700$1500 \mathrm{~m}$ asl.). The annual rainfall is $396 \mathrm{~mm}$ and the mean annual temperature is $14.17^{\circ} \mathrm{C}$. The majority of the massif is made of hard dolomitic limestones and marls. The most widespread forest formations in the area are composed of Aleppo pine, holm oak, Atlas cedra, Phoenicean juniper, cade juniper, globe daisies, narrow-leaved mock privet, oriental hawthorn (Crataegus laciniata), and Eucalyptus tree (Eucalyptus sp.).

The Ouannougha forest (17671 ha) is a part of the mountain range of Bibans, it is located in the province of Bordj Bou Arréridj (3609'35.2"N, 4²12'16.8"E, 900-1280 $\mathrm{m}$ asl.), $420 \mathrm{~mm}$ of precipitation falls annually with a mean annual temperature of $15.6{ }^{\circ} \mathrm{C}$. The trees composing this forest are Aleppo pine, holm oak, Atlas cedra, Phoenician juniper, and cade juniper.
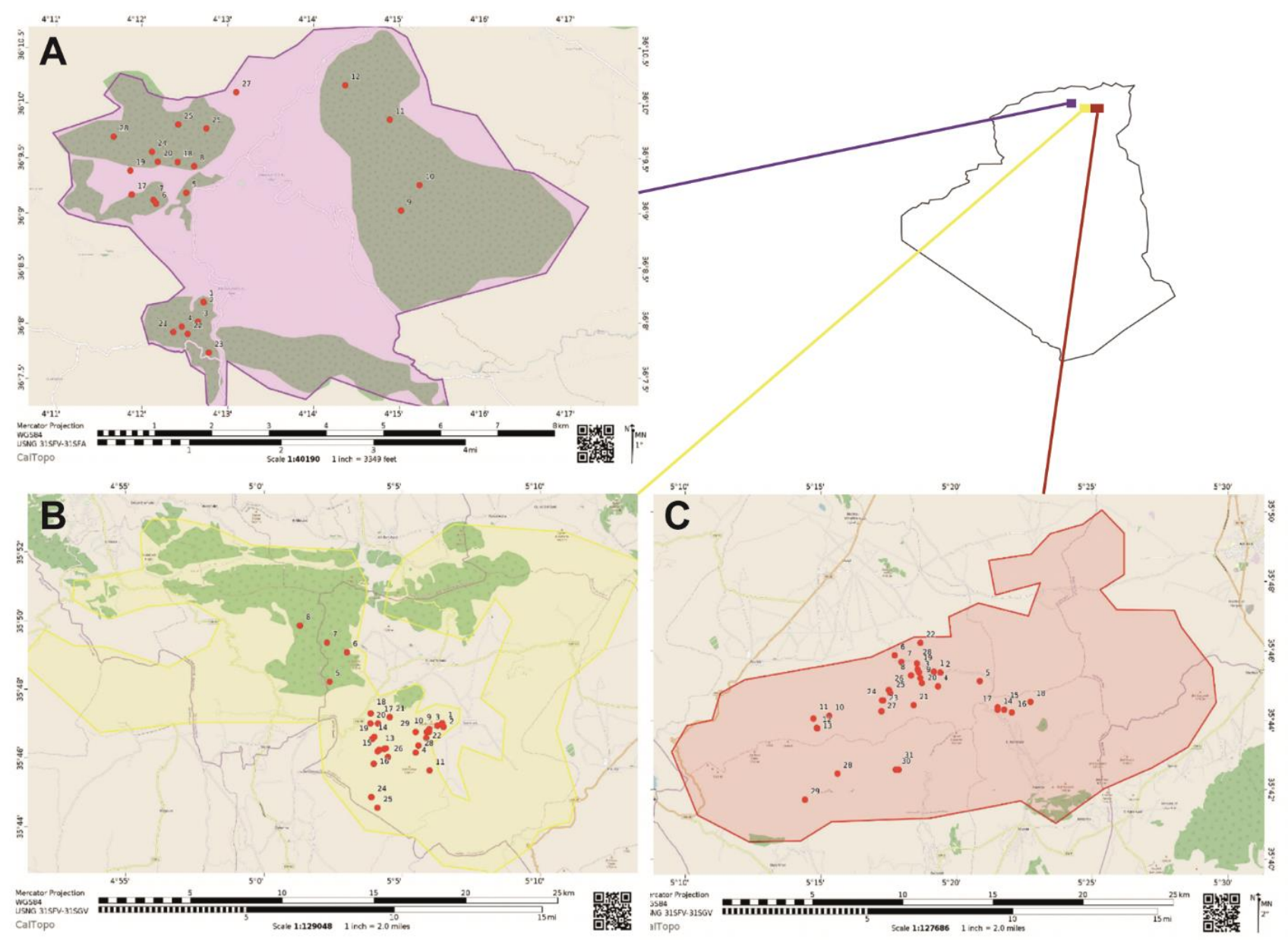

Figure 1. Localization of the sampling sites in Ouenougha (A) Ouled Tebben (B) and Boutaleb (C) forests in North-Eastern Algeria 
Table 1. Sampling dates for each forest studied

\begin{tabular}{cccc}
\hline \multirow{2}{*}{ Sampling } & \multicolumn{3}{c}{ Date } \\
\cline { 2 - 4 } & Boutaleb & Ouled Tebben & Ouenougha \\
\hline 1 & $2017 / 05 / 24$ & $2017 / 05 / 28$ & $2017 / 06 / 05$ \\
2 & $2017 / 06 / 08$ & $2017 / 06 / 11$ & $2017 / 06 / 13$ \\
3 & $2017 / 06 / 22$ & $2017 / 06 / 25$ & $2017 / 06 / 26$ \\
4 & $2017 / 07 / 05$ & $2017 / 07 / 06$ & $2017 / 07 / 09$ \\
5 & $2017 / 08 / 19$ & $2017 / 07 / 22$ & $2017 / 07 / 23$ \\
6 & $2017 / 08 / 05$ & $2017 / 08 / 13$ & $2017 / 08 / 10$ \\
7 & $2017 / 08 / 19$ & $2017 / 09 / 04$ & $2017 / 08 / 23$ \\
\hline
\end{tabular}

\section{Bark beetles collection and identification}

Bark beetles were collected from Pinus helepensis trees in the three forests. The sampling began in May 2017 and was carried out every 15 days for each forest until September 2017 (Table 1).

At least five colonized trees were chosen randomly in every sampling day, based on direct observation of the bark (trunk, branches) and the presence of boring dust or pitch tubes as indicators of bark beetle infestation. Geographic coordinates were noted for every tree. The bark was removed to access the galleries and collect in situ all present insects, placed in sterile microtubes and then stored at $4^{\circ} \mathrm{C}$. In addition, bark of the same trees was put in plastic bags and examined in the laboratory to collect the insects. The total number of beetles collected for each sampling site was estimated.

Collected insects were observed under a stereomicroscope and grouped in morphotypes for the identification with keys according to their taxonomic characteristics ( Balachowsky 1949; Gil and Pajares 1986; Wood 1986; Alonso-Zarazaga 1988; Pfeffer 1995; AlonsoZarazaga and Lyal 2009).

Reference individuals for each species were stored in ethanol.

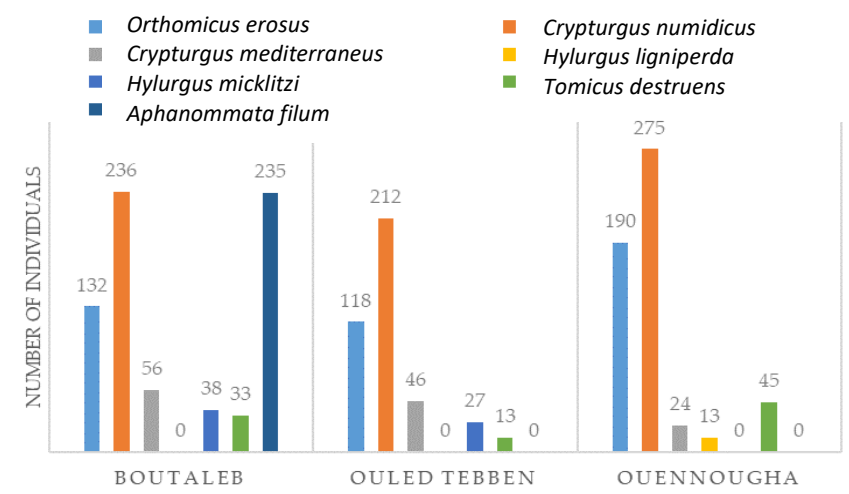

Figure 2. Number of individuals for each species in the three studied forests

\section{RESULTS AND DISCUSSION}

\section{Identification}

In this study, 1629 specimens were collected and identified from 76 Aleppo pine trees. The Boutaleb forest was the most affected with a total number of individuals collected of 666 followed by the Ouenougha and Ouled Tebben forests with 547 and 416 individuals, respectively (Figures 2, 3, and Table 3). A total of 7 species were identified, 6 belonging to the Scolytinae subfamily and one to the Cossoninae subfamily (Table 2).

\section{Scolytinae subfamily}

Tibiae armed on apical and/or lateral margins either by spines or socketed denticles, apical mucro formed by mesal element (compared to Protohijlastes structure); male spiculum gastrale present, antennal club variable, with or without sutures, head narrower than pronotum; pronotum almost never with constriction near middle, pronotum edged on the sides and back. When visible, scutellum usually flushes with elytral surface, often flattened (Wood 1986).

\section{Ipini tribe Bedel, 1888}

Eye shallowly sinuate with lower half narrower than above; protibia with 3-4 socketed teeth; antennal club rarely obliquely truncate (Pityokteines. Orthotomicus), procoxae contiguous, intercoxal piece longitudinally emarginate to absent, never complete; elytra moderately sulcate to elaborately excavated, with lateral margin usually armed by tubercles or spines; pronotum more strongly declivous on anterior third, asperities usually larger; worldwide (Wood 1986)

\section{Orthomicus erosus Wollaston, 1857 (Mediterranean pine beetle)}

Close to the genus Ips, from which it is distinguished by the straightness of its declivity whose apical edge is not explained backward.

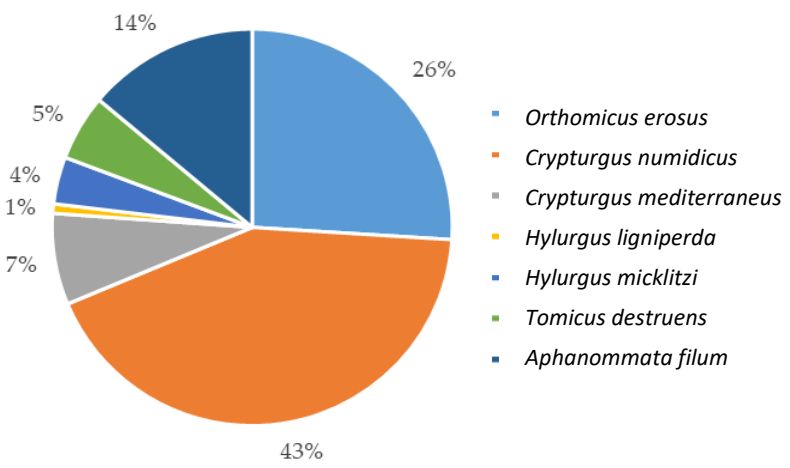

Figure 3. Number of individuals for each species in the three studied forests 
Table 2. Identified species in the three forests

\begin{tabular}{|c|c|c|c|c|c|}
\hline $\begin{array}{c}\text { Sub } \\
\text { family }\end{array}$ & Tribe & Species & Common name & Habitat & Host species \\
\hline \multirow{6}{*}{ 䒿 } & 节 & $\begin{array}{l}\text { Orthomicus } \\
\text { erosus }\end{array}$ & $\begin{array}{l}\text { Mediterranean pine } \\
\text { beetle }\end{array}$ & $\begin{array}{l}\text { Central Europe, Mediterranean area, Sardinia, } \\
\text { Atlantic Islands, British Islands, North } \\
\text { Africa, Central Asia, China. Introduced in } \\
\text { South Africa, Chile, Finland, Sweden, Fiji } \\
\text { Islands, and United States }\end{array}$ & $\begin{array}{l}\text { Pinus radiata, } P \text {. pinea, } P \text {. } \\
\text { sylvestris, } P \text {. pinaster, } P . \\
\text { halepensis, } P \text {. nigra }\end{array}$ \\
\hline & \multirow{3}{*}{ 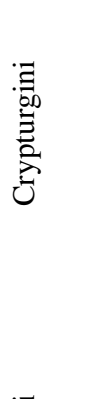 } & $\begin{array}{l}\text { Crypturgus } \\
\text { numidicus }\end{array}$ & & $\begin{array}{l}\text { Bosnia Herzegovina, Bulgaria, Croatia, } \\
\text { France, Greece, Italy, Malta, Spain, Algeria, } \\
\text { Tunisia, Turkey. }\end{array}$ & $\begin{array}{l}\text { Pinus halepensis, } P \text {. pinaster, } \\
P . \text { pinea, } P \text {. nigra, } P \text {. brutia, } \\
\text { Abies numidica, A. pinsapo, } \\
\text { Cedrus libani }\end{array}$ \\
\hline & & $\begin{array}{l}\text { Crypturgus } \\
\text { mediterraneus }\end{array}$ & & $\begin{array}{l}\text { Croatia, France, Greece, Italy Portugal, } \\
\text { Spain, Algeria, Morocco, Tunisia, Cyprus, } \\
\text { Turkey }\end{array}$ & $\begin{array}{l}\text { Pinus halepensis, } P \text {. pinaster, } \\
P . \text { nigra, P. brutia }\end{array}$ \\
\hline & & $\begin{array}{l}\text { Hylurgus } \\
\text { ligniperda }\end{array}$ & $\begin{array}{l}\text { Red-haired pine bark } \\
\text { beetle }\end{array}$ & $\begin{array}{l}\text { Central and South Europe, Caucasus, Turkey, } \\
\text { Algeria, New Zealand. the Canary Islands, } \\
\text { the United States, South Africa, Australia, } \\
\text { Chile, Brazil, Uruguay and Sri Lanka }\end{array}$ & $\begin{array}{l}\text { Pinus pinaster, } P \text {. brutia, } P \text {. } \\
\text { halepensis, } P \text {. pinea. }\end{array}$ \\
\hline & \multirow{2}{*}{ 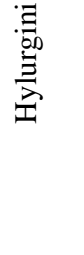 } & Hylurgus micklitzi & & $\begin{array}{l}\text { Northern Africa, Mediterranean regions of } \\
\text { Europe, Asia Minor, Caucasus }\end{array}$ & $\begin{array}{l}\text { P. halepensis, } P \text {. brutia, } P \text {. } \\
\text { pinaster, } P \text {. pinea and } P \text {. nigra }\end{array}$ \\
\hline & & Tomicus destruens & Pine shoot beetle & $\begin{array}{l}\text { Algeria, Tunisia, Morocco, France, Croatia, } \\
\text { Slovenia, Serbia, Bosnia Herzegovina and } \\
\text { Montenegro, Greece, Italy, Portugal, Spain, } \\
\text { Madeira Islands, Cyprus, Israel, Turkey, and } \\
\text { South-Western Asia. }\end{array}$ & $\begin{array}{l}P . \text { halepensis, } P \text {. pinaster, } P \text {. } \\
\text { pinea, } P \text {. brutia and } P \text {. } \\
\text { canariensis. }\end{array}$ \\
\hline 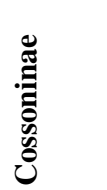 & $\begin{array}{l}: \Xi \\
\stackrel{\Xi}{0} \\
\stackrel{\Xi}{\simeq}\end{array}$ & $\begin{array}{l}\text { Aphanommata } \\
\text { filum }\end{array}$ & & $\begin{array}{l}\text { Italy, Spain, France, Algeria, Bulgaria, } \\
\text { Croatia and Albania }\end{array}$ & Pinus sp. \\
\hline
\end{tabular}

Note: Balachowsky (1949); Gil and Pajares (1986); Pfeffer (1995); Haack (2004); Lopez et al. (2007); Lieutier et al. (2016); Skuhrovec et al. (2018)

Table 3. Number of individuals collected for each species in the three forests studied at each sampling date.

\begin{tabular}{|c|c|c|c|c|c|c|c|}
\hline \multirow{2}{*}{$\begin{array}{c}\text { Site and date } \\
\text { of sampling }\end{array}$} & \multicolumn{7}{|c|}{ Number of individuals } \\
\hline & O. erosus & C. numidicus & C. mediterraneus & H. ligniperda & H. micklitzi & T. destruens & A. filum \\
\hline \multicolumn{8}{|l|}{ Boutaleb forest } \\
\hline $2017 / 05 / 24$ & l & 24 & / & / & / & 28 & 30 \\
\hline $2017 / 06 / 08$ & l & 22 & l & l & / & 3 & 25 \\
\hline $2017 / 06 / 22$ & l & 44 & / & / & / & / & 32 \\
\hline $2017 / 07 / 05$ & 32 & 50 & l & l & / & l & 21 \\
\hline $2017 / 07 / 19$ & 22 & 17 & 20 & / & 1 & / & 33 \\
\hline $2017 / 08 / 05$ & 37 & 25 & 10 & l & 12 & l & 44 \\
\hline $2017 / 08 / 19$ & 26 & 29 & 26 & l & 3 & l & 50 \\
\hline Total & 117 & 211 & 56 & 0 & 16 & 31 & 235 \\
\hline \multicolumn{8}{|l|}{ Ouled Tebben forest } \\
\hline $2017 / 05 / 28$ & 15 & 49 & l & / & / & 13 & / \\
\hline $2017 / 06 / 11$ & 18 & 24 & l & / & 9 & l & / \\
\hline $2017 / 06 / 25$ & 30 & 48 & l & l & I & l & l \\
\hline $2017 / 07 / 06$ & 7 & 26 & 10 & l & 11 & l & I \\
\hline $2017 / 07 / 22$ & 10 & 32 & 17 & l & 7 & l & l \\
\hline $2017 / 08 / 13$ & 20 & 32 & 49 & l & l & l & l \\
\hline 2017/09/04 & 18 & l & l & l & / & l & l \\
\hline Total & 118 & 212 & 46 & 0 & 27 & 13 & 0 \\
\hline \multicolumn{8}{|l|}{ Ouenougha forest } \\
\hline $2017 / 06 / 05$ & 30 & 42 & / & / & / & 15 & l \\
\hline $2017 / 06 / 13$ & 22 & 37 & l & l & / & 11 & l \\
\hline $2017 / 06 / 26$ & 18 & 32 & l & l & / & 9 & l \\
\hline $2017 / 07 / 09$ & 37 & 48 & l & / & / & 10 & l \\
\hline $2017 / 07 / 23$ & 31 & 44 & 9 & 4 & l & l & I \\
\hline $2017 / 08 / 10$ & 36 & 33 & 15 & I & l & l & I \\
\hline $2017 / 08 / 23$ & 16 & 29 & I & 9 & I & I & I \\
\hline Total & 190 & 275 & 24 & 13 & 0 & 45 & 0 \\
\hline
\end{tabular}


Adults are 3 to $3.8 \mathrm{~mm}$ in size, orange or yellowish when young and black at maturity. Dorsally the head is not visible, the anterior of the pronotum has transverse spicule bands. The antennae is composed of 5 segments, the second one is shorter than the first. Antennae mace sutures are procurved upwards in their middle in an arc shape. The margin of the elytral declivity is concave with 4 teeth on each side, the second ones are the largest and fused to the base of the third one. The teeth are more reduced in the females, presenting 3 small denticles, since the third pair is small. Elytra with deep and regular striae, smooth or punctuated interstriae with long intervals. Pilosity is present all over the body (Balachowsky 1949; Wood 1986; Lopez et al. 2007).

Galeries: Irregular star-shaped gallery with 2 or 3 arms, 4 to $8 \mathrm{~cm}$ long, sub-cortical in decaying trees.

\section{Crypturgini tribe LeConte, 1876}

Small size species, antennal funicle 2-or 3-segmented, club with sutures on posterior face about equal to those on anterior face; pronotum feebly declivous on anterior half and unarmed, punctuated, reticulate in many species (Balachowsky 1949; Wood 1986).

\section{Crypturgus numidicus Ferrari, 1867}

The genus Crypturgus comprises the smallest species within Scolytidae (0.8-1.5 mm). Crypturgus species exhibit a narrow-shaped and cylindrical elongated body (Figure 4), and a brown or black colour with shiny or matt reflections. Antenna funiculus is composed of 2 short segments, with an oval-shaped club provided with a fine and incomplete digitula, diffuse sutures rejected at the end. Long and narrow elytra, evenly rounded declivity. Breeding in the bark of the trunk and branches of decaying pines previously infested by more aggressive species such Orthomicus, egg galleries forming a confused system partially bored into the bark thickness.

Has a size of 1.5-1.6 mm, antenna funiculus composed of 2 segments, antenna head formed by a single segment. Light colored, pronotum and underside of body more or less dark brown, elytra are much lighter and yellowish. Reflections slightly shiny. Stocky, broad, robust species, especially in the female, whose apical brushes of the elytra are very dense. Pronotum totally dotted. It has a convex and smooth elytral declivity, without a denticular processes, bristles of the interstries at least twice as long as the stries. Limited to the Mediterranean region.

Galleries: forming a marbled network that penetrates the thickness of the bark, rapidly reducing it to a spongy mass that is abandoned as soon as it dries out.

Nests in the bark of the trunk and branches of dying pine trees attacked by more aggressive species.

Other scientific names: Crypturgus abbreviatus Eggers, Crypturgus barbeyi Strohmeyer, Crypturgus brevipennis Reitter

\section{Crypturgus mediterraneus Eichhoff, 1889}

Has a size of 1,1-1,5 mm. Longer, slender shape (Figure 4). Silks of interstries shorter and more regular than in $C$. numidicus, arranged in a single row. Pronotum longer than wide with parallel sides beyond the middle, with dense and tight punctuation, devoid of short bristle brushes at the apex of the elytra replaced with scattered silks denser than on the rest of the elytra.

Galleries: forming an irregular network that penetrates the thickness of the bark. Nests in the bark of the trunk of dying pine trees attacked by more aggressive species.

Host plants: Pinus halepensis, $P$. pinaster, $P$. nigra, $P$. brutia (Pfeffer 1995).

\section{Hylurgini tribe Gistel, 1848}

Pronotum, elytra and abdomen fully free of scales. Anterolateral areas of pronotum unarmed; precoxal costa on prothorax absent. Antennal funicle composed of 5 to 7 segments. Head extended forward in form of short rostrum. Mesal surface of elytra at suture with interlocking groove and flange continued to base without a series of nodules or cavities immediately behind scutellum (Balachowsky 1949; Wood 1986).

\section{Hylurgus ligniperda Fabricius, 1787}

Elongated and cylindrical in appearance, with a size of 4.5-5.8 $\mathrm{mm}$. General color of the body is black-brown with reddish antennae (Figure 4). Pronotum and elytra are dark brown in color. Dotted and hairy pronotum, with a smooth longitudinal midline. Pronotum coarsely and uniformly punctuated over its entire surface by large closely spaced dots of irregular diameter and not very deep. Posterior edge of pronotum is straight. Lateral pronotum hairiness are less abundant but longer than the sides of elytra hairiness. Antenna is composed of 6 segments. Elytra with irregular hairiness. Striations formed by a row of large, regularly spaced, shallow circular dots. Wide but rough interstries.

\section{Hylurgus micklitzi Wachtl, 1881}

Has a size of 3.2-4.4 mm. Differs from $H$. ligniperda by its smaller size (Figure 4). Another differential character, from $H$. ligniperda, is the length of the lateral silks of the pronotum, which are the same size as the elytrals, while they are longer in $H$. ligniperda.

Galleries: At the base of the trunk of which it nests, driving its oblique galleries into the thickness of the bark. Can also grow on large bare roots. The mother gallery measures 10-16 cm, the larval galleries are numerous, irregular, long and intertwined (Balachowsky 1949).

\section{Tomicus destruens Wollaston, 1865}

Adults are 3.0-5.3 in size. Antennae funiculus formed by 6 segments. Shiny black and finely dotted pronotum inclined forwards in relation to the elytra. Brown elytra in mature adults (Figure 4). Interstries with a row of granules, except in the second interstrie of the elytral declivity, where the granules disappear.

Galleries: The female bore a longitudinal uniramous gallery in the middle-upper part of stem and large branches, sapwood is little affected. The tunnel is about 8 to $10 \mathrm{~cm}$ long and 3 to $4 \mathrm{~mm}$ wide, the larval galleries develop in the bark thickness without affecting sapwood. 


\section{Cossoninae subfamily}

Round eyes, long procoxal part of prosternum, hypostomal spine, terminal curved uncus, inner grooming comb.

\section{Rhyncolini tribe Le Conte, 1876}

Mesoventrite more or less strongly depressed below level of metaventrite. Procoxal cavities narrowly separated.
Aphanommata filum Mulsant \& Rey, 1858

Eyes slightly visible in dorsal view, flat, situated low on head, in lateral view with ventral margin of rostrum directed towards middle or lower one-half of eye. Adults are 2.30$2.80 \mathrm{~mm}$ in size, pronotum presenting rough and dense punctures (Figure 4), the space between the punctures is smaller than the diameter of punctures. Sides of pronotum are parallel (Alonso-Zarazaga 1988; Skuhrovec et al. 2018).
A

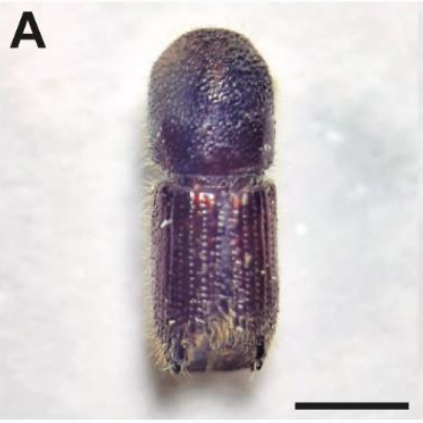

C

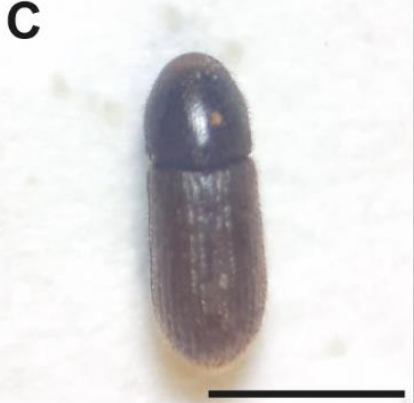

E

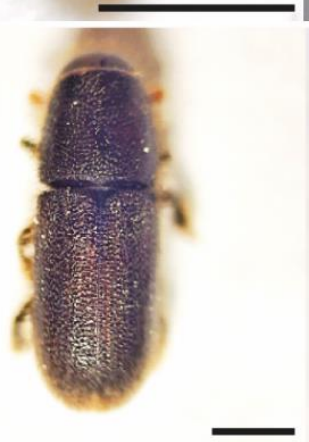

B
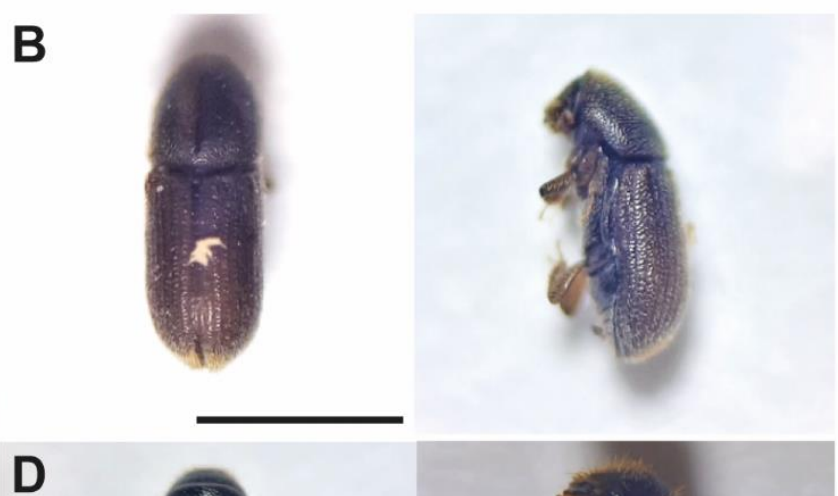

D
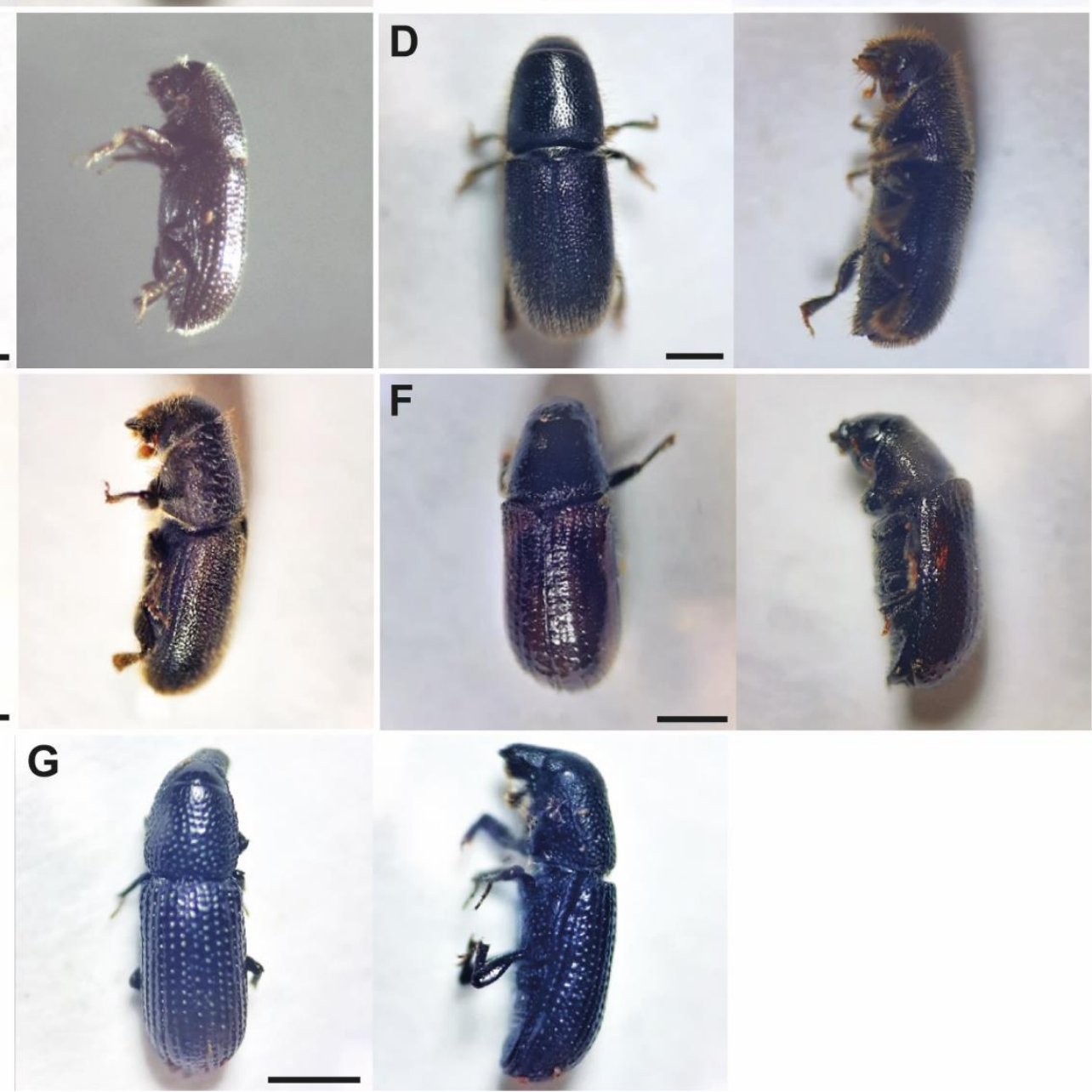

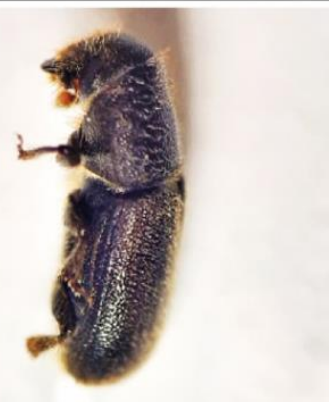

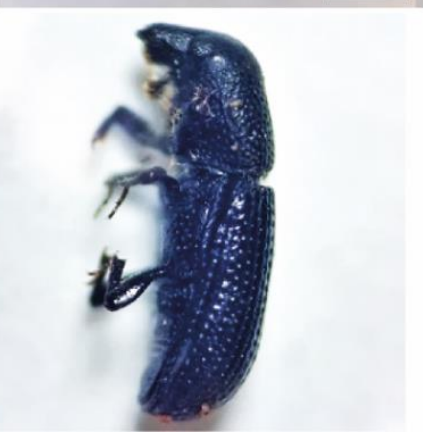

Figure 4. The different species of bark beetles identified. A. Orthotomicus erosus; B. Crypturgus numidicus; C. Crypturgus mediterraneus; D. Hylurgus ligniperda; E. Hylurgus micklitzi; F. Tomicus destruens; G. Aphanommata filum 


\section{Discussion}

This study investigated the diversity of bark beetle species in the North-Eastern region of Algeria for the first time. Seven species were identified, unevenly distributed between the three forests. Crypturgus numidicus was the most abundant species in the three forests, followed by Orthomicus erosus and Tomicus destruens.

Orthomicus erosus and T. destruens were the only species found on living trees. These two species are common on Pinus throughout the Mediterranean basin including the semi-arid regions in Algeria (Balachowsky 1949; Chakali 2004; Lopez et al. 2007; Lieutier et al. 2016). All Mediterranean bark beetles that are able to colonize living trees use the host exhaustion strategy. Species such as $O$. erosus, $H$. ligniperda, and $C$. micklitzi use aggregation pheromones to attract other individuals and thus massively attack the trees (Lieutier et al. 2016). On the other hand, Tomicus destruens is attracted by terpenes emitted from wounds in trees attacked by pioneer bark beetles. All these bark beetle species are associated with xylophagous fungi which probably play a role in the colonization of the host trees.

Tomicus destruens has been reported on Aleppo pines in the Djelfa region (Chakali 2004). Another study showed the presence of $T$. destruens in the Tlemcen region in the extreme east of Algeria (Nichane et al. 2013). Females of $T$. destruens preferentially seek for the northern slopes of the relief and the southern side of the tree to make their maternal gallery. According to Chakali (2007), Mediterranean pine forests have been confronted with $T$. destruens over the last two decades. This species is multiplying rapidly due to the physiological stress of Aleppo pines caused by climate change (Chakali 2004; Guit et al. 2016). This species which has long been confused with the neighboring species Tomicus piniperda, is responsible for the dieback of Aleppo pine forests in the semi-arid regions of Algeria (Guit et al. 2016).

It is clear that the colonization of Aleppo pines is initiated by $T$. destruens, a more aggressive primary species, followed by $O$. erosus which is considered a secondary species (Lopez et al. 2007; Sangüesa-Barreda et al. 2015; Lieutier et al. 2016). Attacks by these two bark beetle species in coniferous forests rely on two complementary factors: the existence of trees weakened by stress and a certain level of pest population (Lieutier and Levieux 1985).

In the region of Zaragoza in Spain, galleries of $O$. erosus occupy a large area of the attacked trees compared to $T$. destruens. The density of galleries of $O$. erosus on attacked Aleppo pine trees was higher than that of $T$. destruens (Sangüiesa-Barreda et al. 2015). In Algeria, $O$. erosus can also colonize Atlas cedar trees (Talbi and Bouhraoua 2015). In a recent survey in Europe, O. erosus was the most commonly found species in Portugal, Spain, France, Greece, Italy and Hungary (Faccoli et al. 2020). When reaching a high population density, O. erosus can overwhelm the host defenses, thus causing tree mortality (Faccoli et al. 2020).

Although $O$. erosus is considered an important pest in many regions of the Mediterranean basin, many consider it a secondary pest. In our study, $O$. erosus was found on living trees in Boutaleb forest, suggesting that it can be a serious pest in semi-arid regions.

Species of the genus Crypturgus are secondary bark beetles that occupy biotypes previously colonized by other species and do not affect healthy trees (Lieutier et al. 2016). For instance, very often trees colonized by $O$. erosus or T. destruens are later colonized by Crypturgus numidicus. Very few studies have focused on this species, which is common throughout Algeria and the most common bark beetle in the forests studied here. It was reported for the first time in the Babors massif (Peyerimhoff 1919). In the three forests studied, $C$. numidicus was sampled from the bark of trees colonized by $O$. erosus. This confirms that this species nests in the bark of trunks and branches of dying Pine trees attacked by other bark beetles (Balachowsky 1949). Taking advantage of the entrances to the galleries of other species, the galleries of $C$. numidicus are bored irregularly throughout the thickness of the Aleppo pine bark, and these galleries are abandoned as soon as the bark dries out (Balachowsky 1949). Crypturgus mediterraneus is poorly spread and was detected here only in the forests of Boutaleb and Ouled Tebben. This species which has been little studied, is often misidentified as C. numidicus (Balachowsky 1949). $C$. mediterraneus has been sampled in the thick bark of the trunks of trees colonized by $O$. erosus, where it uses the gallery systems of other species to penetrate and lay eggs. The larval galleries are highly branched and start from the galleries of other species (Lieutier et al. 2016). This species colonizes the middle or upper part of the trunks of Aleppo pines (Markalas 1997).

Hylurgus species are secondary bark beetles, attacking only weak or dead trees. Hylurgus micklitzi was present in all of the studied forests, but it was found only in decayed trees. By contrast, H. ligniperda was present only in Ouennougha forest. Females settle in the basal part of the trunk and exposed roots of dead or weakened trees. Several authors have reported the presence of these species in Algeria (Balachowsky 1949; Pfeffer 1995), and for instance, Nichane (2013) reported the presence of $H$. ligniperda in the region of Tlemcen.

Aphanommata filum live in conifer trunks, it has already been observed in Algeria (Folwaczny 1973; Alonso-Zarazaga 1988). This poorly known species were abundantly found under the trunk bark of Aleppo pines in the Boutaleb forest, with galleries dug into the sapwood of dead trees. This is consistent with the findings of H. Jordal (Jordal 2014), which showed that Rhyncolini species live in the wood and under the bark of dead trees, adults lay eggs in excavated tunnels, and show similar behavior as Scolytidae.

In conclusion, 6 bark beetle species and one Cossoninae species were recorded for the first time in the center of the East region of Algeria. The diversity of bark beetles in the studied region is low compared to other countries. Among the individuals collected, $T$. destruens and $O$. erosus were the only species found in living trees, demonstrating that $O$. erosus is also capable of attacking stressed trees while it is usually considered as a secondary beetle. Secondary 
species such as C. numidicus, C. mediterraneus, $H$. ligniperda and $H$. micklitzi do not represent a serious threat to Aleppo pine trees. Nevertheless, further studies are needed to extend the sampling, for instance, to other region forests, to obtain a larger picture of the diversity of bark beetles partly responsible for the decline of Aleppo pine forests in eastern Algeria.

\section{ACKNOWLEDGEMENTS}

Special thanks to Ain Ouelmen, Ouled Tebben and Haraza Forest districts, Algeria for helping us to access the different sites. This research was funded by Program Hubert Curien Tassili (PHC code 17MDU977).

\section{REFERENCES}

Alonso-Zarazaga MA. 1988. The genus Aphanommata Wollaston, 1873 in the Old World (Coleoptera: Curculionidae, Cossoninae). Insect Syst Evol 19: 325-331. DOI: 10.1163/187631289X00195.

Alonso-Zarazaga MA, Lyal CHC. 2009. A catalogue of family and genusgroup names in Scolytinae and Platypodinae with nomenclatural remarks (Coleoptera: Curculionidae). Zootaxa 2258: 1-134. DOI: 10.11646/zootaxa.2258.1.1

Anderegg WRL, Hicke JA, Fisher RA, Allen CD, Aukema J, Bentz B, Hood S, Lichstein JW, Macalady AK, Mcdowell N, Pan Y, Raffa K, Sala A, Shaw JD, Stephenson NL, Tague C, Zeppel M. 2015. Tree mortality from drought, insects, and their interactions in a changing climate. New Phytol 208: 674-683. DOI: 10.1111/nph.13477.

Balachowsky A. 1949. Coléoptères Scolytides. Faune de France No 50. Fédération Française des Sociétés de Sciences Naturelles, Paris. [French]

Bao YB, Na L, Han A, Guna A, Wang F, Liu X, Zhang J, Wang C, Tong S, Bao YH. 2020. Drought drives the pine caterpillars (Dendrolimus spp.) outbreaks and their prediction under different RCPs scenarios: A case study of Shandong Province, China. For Ecol Manag 475: 118446. DOI: $10.1016 /$ j.foreco.2020.118446.

Chakali G. 2004. Statut spécifique de l'hylésine Tomicus (ColeopteraScolytidae) de la région semi-aride de Djelfa (Algérie). Annales de 1'Institut National Agronomique 25: 31-41. [French]

Chakali G. 2007. Stratégie d'attaque de l'hylésine Tomicus destruens (Wollaston 1865) (Coleoptera: Scolytidae) sur le pin d'Alep en zone semi-aride (Algérie, Djelfa). Ann Soc Entomol Fr 43: 129-137. DOI: 10.1080/00379271.2007.10697502. [French]

Davi H, Durand-Gillmann M, Damesin C, Delzon S, Petit C, Rozenberg P, Sabatier SA, Chadœuf J, Boutte B, Boivin T. 2020. Distribution of endemic bark beetle attacks and their physiological consequences on Pinus halepensis. For Ecol Manag 469: 118187. DOI: 10.1016/j.foreco.2020.118187.

Faccoli M, Gallego D, Branco M, Brockerhoff EG, Corley J, Coyle DR, Hurley BP, Jactel H, Lakatos F, Lantschner V, Lawson S, Martínez G, Gómez DF, Avtzis D. 2020. A first worldwide multispecies survey of invasive Mediterranean pine bark beetles (Coleoptera: Curculionidae, Scolytinae). Biol Invasions 22: 1785-1799. DOI: 10.1007/s10530-020-02219-3.

Folwaczny B. 1973. Identification table of the Palaarctic Cossoninae (Coleoptera, Curculionidae) without the genera occurring only in China and Japan, together with information on distribution. Entomologische Blätter für Biologie und Systematik der Käfer 65$180 . \mathrm{h}$
Gil LA, Pajares JA. 1986. Los escolítidos de las coníferas en la Península Ibérica. Monografías INIA 53, Ministerio de Agricultura, Pesca y Alimentación, Instituto Nacional de Investigaciones Agrarias. [Spanish]

Guit B, Nedjimi B, Chakali G, Guibal F. 2016. État sanitaire des peuplements de pin d'Alep (Pinus halepensis MILL.) Dans le massif forestier de Senalba (Djelfa, Algérie). Rev Ecol-Terre Vie 71: 156167. [French]

Haack RA. 2004. Orthotomicus erosus: A new pine-infesting bark beetle in the United States. Newslett Michigan Entomol Soc 49: 3.

Jordal BH. 2014. Cossoninae. In: Leschen B (eds). Arthropoda: Insecta: Coleoptera. Volume 3: Morphology and Systematics (Phytophaga). DeGruyter, Germany.

Lieutier F, Mendel Z, Faccoli M. 2016. Bark beetles of Mediterranean conifers. In: Timothy P, François L (eds.). Insects and Diseases of Mediterranean Forest Systems. Springer, Nederland. DOI: 10.1007/978-3-319-24744-1_6.

Lieutier F, Levieux J. 1985. Les relations conifères-scolytides : importance et perspectives de recherches. Annales des sciences forestières, INRA/EDP Sciences $42: 359-370$. [French]

Lieutier F, Bermudez-Torres K, Cook J, Harris MO, Legal L, Sallé A, Schatz B, Giron D. 2017. From plant exploitation to mutualism. Adv Bot Res 81: 55-109. DOI: 10.1016/bs.abr.2016.10.001.

Lopez S, Ochoa PR, Carlos Iturrondobeitia J, Goldarazena A. 2007. Los Escolítidos de las Coníferas del País Vasco: Guía Práctica para su identificación y control. Servicio Central de Publicaciones del Gobierno Vasco, Spain. [Spanish]

Markalas S. 1997. Frequency and distribution of insect species on trunks in burnt pine forests of Greece. Mitt Schweiz Entomol Ges 70: 57-61.

Morcillo L, Gallego D, González E, Vilagrosa A. 2019. Forest decline triggered by phloem parasitism-related biotic factors in Aleppo Pine (Pinus halepensis). Forests 10: 608. DOI: 10.3390/f10080608.

Nichane M, Bouchikhi Tani Z, Anouar Khelil M, 2013. Contribution à l'étude de l'entomofaune de quelques espèces résineuses de la région des Traras Occidentaux (Tlemcen-Algérie). Leban Sci J 14: 25-31. [French]

Paine TD, Raffa KF, Harrington TC. 1997. Interactions among scolytid bark beetles, their associated fungi, and live host conifers. Ann Rev Entomol 42: 179-206. DOI:10.1146/annurev.ento.42.1.179.

Peyerimhoff P. 1919. Notes sur la biologie de quelques Coléoptères phytophages du Nord Africain (3ème série). Ann Soc Entomol Fr 88: 169-258. [French]

Pfeffer A. 1995. Zentral und westpaläarktische. Borken und Kernkäfer. Basel. [Germany]

Sangüesa-Barreda G, Linares JC, Camarero JJ. 2015. Reduced growth sensitivity to climate in bark-beetle infested Aleppo pines: Connecting climatic and biotic drivers of forest dieback. For Ecol Manag 357: 126-137. DOI: 10.1016/j.foreco.2015.08.017.

Sauvion N, Calatayud P-A, Thiéry D, Marion-Poll F. 2013. Interactions insectes-plantes. In: Sauvion N, Calatayud P-A, Thiéry D, MarionPoll F. Vector-Borne Phytopathogenic Bacteria. Quae Editions, IRD Editions. DOI: 10.4000/books.irdeditions.22185.

Skuhrovec J, Hlaváč P, Batelka J. 2018. Review of Cape Verde Aphanommata Wollaston, 1873 (Coleoptera: Curculionidae: Cossoninae) with description of new species, larva and notes on biology and distributional patterns. Diversity 10: 28. DOI: 10.3390/d10020028.

Suárez-Vidal E, Sampedro L, Voltas J, Serrano L, Notivol E, Zas R. 2019. Drought stress modifies early effective resistance and induced chemical defenses of Aleppo pine against a chewing insect herbivore. Environ Exp Bot 162: 550-559. DOI: 10.1016/j.envexpbot.2019.04.002.

Talbi Y, Bouhraoua RT. 2015. Complexe xylophage associé au dépérissement du cèdre de l'atlas au Bélezma (Algérie). Leban Sci J 16: 97. [French]

Wood SL. 1986. A reclassification of the subfamilies and tribes of Scolytidae (Coleoptera). Great Basin Naturalist Memoirs 10: 111. 